\title{
Role of Pharmacists
}

\section{Margherita Galassi and Maria Estela Moreno-Martínez}

The pharmacist has a key role in the management of CAR-T therapies. Selection, ordering, reception, storage, preparation of the product for infusion, and dispensing of CAR-T therapies are some of the pharmacy service responsibilities (Black 2018; Moreno-Martínez et al. 2020; Booth et al. 2020). The pharmacist requires specific training, ensuring coordination with all the professionals in the multidisciplinary team who are involved in the management of these therapies, as summarized in Table 41.1.

The pharmacist must also know which types of CARs are available and can arrive in the future. CAR-T cells are currently indicated for the treatment of B-cell acute lymphoblastic leukaemia and diffuse large B-cell lymphoma, two haematological diseases that share expression of the CD-19 antigen, but the target antigens are potentially many; therefore, the pharmacist must receive training that takes into account new future possibilities. An example of other options is the advanced phase experimentation of CAR-T cells and anti-B-cell maturation antigen (BCMA) for multiple myeloma pathologies.

CAR-T cells are just the beginning, and CAR-Technology is being applied to other immune cells:

- CAR natural killer (NK) cells: CAR-NK.

- CAR macrophages (M): CAR-M.

M. Galassi

Centrale Produzione Farmaci, Hospital Pharmacy, National Cancer Institute of Milan,

Milan, Italy

e-mail: Margherita.Galassi@istitutotumori.mi.it

M. E. Moreno-Martínez ( $\triangle)$

Department of Pharmacy, Hospital de la Santa Creu i Sant Pau, Barcelona, Spain

e-mail: MMorenoma@santpau.cat 
Table 41.1 Pharmacist's responsibilities

Pharmacist-specific training

Selection and indication for CAR-T cell therapy

- Review and approval for formulary addition

- Patient eligibility criteria

Ordering: know each procedure to order the drug

Reception

- Check integrity of the product, labelling, and temperature compliance

- Check certificate of analysis

Storage and handling

- Manage products stored at ultra-cold temperatures

- Action plan if temperature deviation

Dispensing

- Validate lymphodepleting chemotherapy and coordinate date of dispensing and time planned for infusion

- Ensure chain of identity of cell product

- Check defrosting procedure. Record the date and time of all the procedures

Administration: confirm procedure and doses of tocilizumab stock ready to use

Follow-up

- Drugs permitted and contraindicated

- Monitoring and management of toxicities

- Ensure appropriate treatment is available

Patient and staff education

Finally, CAR-T cells may be effective against solid tumours, and the main problem related to the accessibility of the antigen can be solved in patients suffering from glioblastoma and neuroblastoma with the injection of the cells on site.

The complexity of these therapies requires the intervention of the pharmacist whose training must include implementation and management of advanced biotechnological procedures; therefore, specific skills not only in the preparation of classic chemotherapies and monoclonal antibodies but also in how to handle, store, and manage novel therapies and the specific medical devices that could be required are needed.

One of the most important pharmacist interventions is patient follow-up, intended to monitor toxicities, adverse events, and concomitant and contraindicated drugs. Cytokine release syndrome is an extremely serious event that must be monitored by a multidisciplinary team in which the pharmacist is the reference figure for the management of rescue drugs and pharmacovigilance studies.

\section{Key Points}

- The pharmacist requires specific training in the management of CAR-T therapies, ensuring coordination with all the professionals in the multidisciplinary team.

- The pharmacist must know the types of CARs available and what will arrive quite soon.

- New skills are needed to handle and store CARs and to follow-up with patients. 


\section{References}

Black A. Pharmacy institutional readiness for marketed CAR-T therapy: checklists for pharmacy services. Version 3.0. Specialist Pharmacy Service; 2018. Available at: https://www.sps.nhs.uk/ wp-content/uploads/2018/10/FINAL-Pharmacy-Institutional-Readiness-for-Marketed-CARTDec-2018.pdf

Booth JP, Kusoski CL, Kennerly-Shah JM. The pharmacist's role in chimeric antigen receptor T cell therapy. J Oncol Pharm Pract. 2020;26(7):1725-31.

Moreno-Martínez ME, Vinent-Genestar J, Muñoz-Sánchez C, Carreras-Soler MJ. Hospital pharmacist's roles and responsibilities with CAR-T medicines. Farm Hosp. 2020;44(1):26-31.

Open Access This chapter is licensed under the terms of the Creative Commons Attribution 4.0 International License (http://creativecommons.org/licenses/by/4.0/), which permits use, sharing, adaptation, distribution and reproduction in any medium or format, as long as you give appropriate credit to the original author(s) and the source, provide a link to the Creative Commons license and indicate if changes were made.

The images or other third party material in this chapter are included in the chapter's Creative Commons license, unless indicated otherwise in a credit line to the material. If material is not included in the chapter's Creative Commons license and your intended use is not permitted by statutory regulation or exceeds the permitted use, you will need to obtain permission directly from the copyright holder. 